E-ISSN: 2808-5361

http://e-journal.fkmumj.ac.id/
Proceeding The First Muhammadiyah

Internasional- Public Health

and Medicine Conference

\title{
ANALYSIS OF THE IMPLEMENTATION OF NOSOCOMIAL INFECTION PREVENTION AND CONTROL IN HOSPITALS (A LITERATURE STUDY)
}

\author{
${ }^{1}$ Amira Mhuthia Adila, ${ }^{2}$ Nur Ramadhan, ${ }^{3}$ Puspa Nujulla, ${ }^{4}$ Putri Dwi Ardiyanti, ${ }^{5}$ Rina Oktavia, \\ ${ }^{6}$ Shelly Fadhilah Muqsith, ${ }^{7}$ Vania Alda Nabilah, ${ }^{8}$ Zalma Nur Khadijah Putri, ${ }^{9}$ Munaya Fauziah \\ Faculty of Public Health, Muhammadiyah University of Jakarta \\ Jl. K.H. Ahmad Dahlan, Cireundeu, Ciputat, Jakarta Selatan, 15419 \\ Email: rinaoktavia44@gmail.com
}

\begin{abstract}
Infections due to health services or Healthcare-Associated Infection (HAI) or known as nosocomial infections are infections that occur in patients during treatment in hospitals or other health facilities. The prevention and control of nosocomial infections is a worldwide challenge. This study aims to examine the literature, articles, or journals of research results regarding the implementation of prevention and control of nosocomial infections in hospitals. The method used is a literature review with 10 journals that were reviewed and written from 2015 to 2020, or written in the last 6 years with the keywords "Analysis of the Implementation of Nosocomial Infection Prevention and Control". The results obtained are 8 journals that have obstacles such as lack of Human Resources (HR), insufficient funds and infrastructure, there are still many officers who have not taken action according to Standard Operating Procedures (SOP), many officers have not received training, there is no incentive for officers., there is an unbalanced workload, the reporting system is not maximized, the use of Personal Protective Equipment (PPE) is not optimal, and cough etiquette has not been carried out by officers. So it is necessary to add things that must be met such as training of officers, completing the needs (facilities and infrastructure) for officers, providing sanctions for officers when violating (not taking actions according to SOPs), providing incentives for officers, and even giving rewards for officers who obey comply SOP, especially given strict supervision from the hospital so that officers and patients do not transmit their disease to each other or other people.
\end{abstract}

Keywords: Nosocomial infection, Implementation of prevention and control 
Volume I Tahun 2021

November 2021
E-ISSN: 2808-5361

http://e-journal.fkmumj.ac.id/
Proceeding The First

Muhammadiyah

Internasional- Public Health

and Medicine Conference

\section{INTRODUCTION}

Infections due to health services or Healthcare-Associated Infection (HAI) or known as nosocomial infections are infections that occur in patients during treatment in hospitals or other health facilities. The infection was not found or was not incubating at the time the patient was admitted. This infection occurs when the patient goes to the hospital and only manifests after the patient is discharged from the hospital. In addition to patients, HAI can occur in health workers and hospital staff (Madjid and Wibowo, 2017).

Infectious diseases related to health services (HAI) are one of the health problems in various countries in the world, including Indonesia. The World Health Organization (WHO) in 2016 stated that $15 \%$ of the total hospitalized patients were part of the incidence of HAI with an incidence rate of $75 \%$ in Southeast Asia and Sub-Saharan Africa which was a factor causing 4-56\% of neonatal deaths (Heriyati, Hatisa, and Astuti, 2020). Based on the results of the CDC survey (2016) in United States hospitals, the incidence of HAI in 2014 reached 722,000 in acute care units and 75,000 patients with HAI died when hospitalized (Sundoro, 2020). Meanwhile, HAI that occurred in Indonesia reached $15.47 \%$, far above developed countries which ranged from 4.8-15.5\%. So it can be concluded that in Indonesia the incidence of HAI in hospitals is still very high (Puspitasari, 2020)

Prevention and control of nosocomial infections is a challenge worldwide because it can lead to morbidity and mortality and increase health costs due to additional treatment and hospitalization time (Agusti, Suryoputro and Kusumastuti, 2019). Nosocomial infections are a serious problem for hospitals. The losses incurred are very burdensome for hospitals and patients. Prevention and control of nosocomial infections is an important effort in improving the quality of hospital medical services (Salawati, 2012).

The high prevalence of HAI is a threat to hospital services. Infection prevention and control activities in health care facilities are very important because they are an indicator of service quality standards and are important for patients, health workers, and visitors. Infection control must be carried out by all health care facilities to protect patients, health workers, and visitors from the incidence of infection by taking into account cost-effectiveness (Cahya et al., 2020).

One of the activities or programs that must be carried out in health care facilities to reduce HAI is the infection prevention and control program or called PPI by the Decree of the Minister of Health No. 27 of 2017 concerning IPC management guidelines in hospitals and other health care facilities. The PPI program consists of planning, implementation, coaching, education, and training, as well as monitoring and evaluation (Agusti, Suryoputro, and Kusumastuti, 2019). 
E-ISSN: $2808-5361$

http://e-journal.fkmumj.ac.id/
Proceeding The First

Muhammadiyah

Internasional- Public Health

and Medicine Conference

\section{METHODS}

The method used in writing this article is a literature review. That is a national literature search that is accessed through Google Scholar, the Garuda portal, and so on. There were 10 journals used in this study, which were written from 2015 to 2020, or written in the last 6 years with the keyword "Analysis of the Implementation of Nosocomial Infection Prevention and Control". The results of all journals are summarized in a matrix containing the year of publication, author's name, title, and research results. The summary matrix of the ten journals is analyzed to conclude to answer the questions of this literature review so that the research objectives are achieved.

\section{RESULTS AND DISCUSSIONS}

Table 1. Summary of the results of the analysis of the implementation and prevention of nosocomial infections in hospitals

\begin{tabular}{|c|c|c|c|c|}
\hline No & Tahun Terbit & Nama Penulis & Judul & Hasil \\
\hline 1. & August 2018 & $\begin{array}{l}\text { Sukfitrianty } \\
\text { Syahrir, } \\
\text { Fitrahmadani } \\
\text { Tirmanidhana, Sitti } \\
\text { Raodhah, Emmi } \\
\text { Bujawati }\end{array}$ & $\begin{array}{l}\text { Analysis of the } \\
\text { Implementation of } \\
\text { Prevention and } \\
\text { Control of } \\
\text { Nosocomial } \\
\text { Infections in the ICU } \\
\text { of Labuang Baji } \\
\text { Hospital, Makassar }\end{array}$ & $\begin{array}{l}\text { The results showed that the } \\
\text { implementation of universal } \\
\text { precautions was carried out by } \\
\text { washing hands with hand wash and } \\
\text { hand rub. Use of Personal } \\
\text { Protective Equipment is used based } \\
\text { on each indication. Management of } \\
\text { medical devices is carried out at } \\
\text { CSSD (Central Sterile Supply } \\
\text { Department). Waste treatment is } \\
\text { separated by type and temporary } \\
\text { storage is carried out. Airborn } \\
\text { precaution placing the patient in the } \\
\text { RPK (Special Treatment Room) } \\
\text { and using a special mask (N95). } \\
\text { Droplet precautions patients can be } \\
\text { placed in RPK, ICU isolation } \\
\text { rooms, or regular beds. The } \\
\text { patient's contact precautions are } \\
\text { placed in a regular patient bed. }\end{array}$ \\
\hline 2. & 2019 & $\begin{array}{l}\text { Ramayanti, Rima } \\
\text { Semiarty, Yuniar } \\
\text { Lestari }\end{array}$ & $\begin{array}{l}\text { Analysis of the } \\
\text { Implementation of } \\
\text { the Nosocomial } \\
\text { Infection Prevention } \\
\text { and Control Program } \\
\text { at the West Pasaman } \\
\text { Hospital } \\
\text { (Accreditation } \\
\text { Standard Version }\end{array}$ & $\begin{array}{l}\text { There are obstacles in } \\
\text { implementing the PPI in West } \\
\text { Pasaman Hospital after being } \\
\text { analyzed with a systems approach. } \\
\text { Input constraints are human } \\
\text { resources, funds, and facilities, } \\
\text { while the process is not optimal } \\
\text { because there are still officers who } \\
\text { have not carried out according to }\end{array}$ \\
\hline
\end{tabular}


Volume I Tahun 2021

November 2021

E-ISSN: 2808-5361

http://e-journal.fkmumj.ac.id/
Proceeding The First

Muhammadiyah

Internasional- Public Health

and Medicine Conference

\begin{tabular}{llll}
\hline No & Tahun Terbit & \multicolumn{1}{c}{ Nama Penulis } & \multicolumn{1}{c}{ Judul } \\
\hline & & & 2012) \\
& & & \\
\hline 3. & December 2019 & Yayang & Analysis of \\
& & Khairunnisa Agusti, & Management \\
& Antono Suryoputro, & Implementation of \\
& Wulan Kusumastuti & the Healthcare- \\
& & Associated Infections \\
& & Prevention and \\
& & Control Committee at \\
& & Tugurejo Hospital, \\
& & Central Java Province
\end{tabular}

Standard Operating Procedures

(SOP).

PPI committee members have not received training evenly, there is no commitment from all officers involved in the PPI program, there are no incentives for PPI committee members, there is an unbalanced workload among PPI committee members, there are still shortages and delays in providing PPI facilities, and compliance officers on hand hygiene is still around $80 \%$.

\begin{tabular}{|c|c|c|c|c|}
\hline 4. & October 2017 & $\begin{array}{l}\text { Tetyana Madjid, } \\
\text { Adik Wibowo }\end{array}$ & $\begin{array}{l}\text { Analysis of the } \\
\text { Implementation of } \\
\text { Infection Prevention } \\
\text { and Control Programs } \\
\text { in the Inpatient Room } \\
\text { of Tebet Hospital in } \\
2017\end{array}$ & $\begin{array}{l}\text { The results showed that most of the } \\
4 \text { actions had been carried out by } \\
\text { nurses well, data analysis used } \\
\text { univariate, bivariate, multivariate } \\
\text { logistic regression. The variable } \\
\text { that most influenced the action was } \\
\text { the reporting of infection. }\end{array}$ \\
\hline 5. & 2017 & Mufidah Al'amri & $\begin{array}{l}\text { Analysis of the } \\
\text { Implementation of } \\
\text { Infection Prevention } \\
\text { and Control at the } \\
\text { Anutapura General } \\
\text { Hospital, Palu- } \\
\text { Central Sulawesi }\end{array}$ & $\begin{array}{l}\text { The results of this study } \\
\text { recommend that the program, } \\
\text { infection prevention, and control at } \\
\text { Anutapura Palu General Hospital be } \\
\text { further improved, especially for } \\
\text { reporting and follow-up of the } \\
\text { incidence of infection in the } \\
\text { hospital. The incidence of infection } \\
\text { in the hospital was found to be still } \\
\text { high above the established standard, } \\
\text { as well as the reporting system that } \\
\text { had not run optimally. }\end{array}$ \\
\hline 6. & April 2015 & $\begin{array}{l}\text { Anugrah Perdana } \\
\text { Masloman, G. D } \\
\text { Kandou, Ch. R. } \\
\text { Tilaar }\end{array}$ & $\begin{array}{l}\text { Analysis of the } \\
\text { Implementation of } \\
\text { Infection Prevention } \\
\text { and Control in the } \\
\text { Operating Room of } \\
\text { Dr. Sam Ratulangi } \\
\text { Hospital Tondano }\end{array}$ & $\begin{array}{l}\text { The results showed that the } \\
\text { implementation of hand hygiene, } \\
\text { use of personal protective } \\
\text { equipment, processing of patient } \\
\text { equipment, waste management, } \\
\text { environmental management, health } \\
\text { care programs, patient placement, } \\
\text { respiratory hygiene, safe injection } \\
\text { practices, and practices for lumbar } \\
\text { puncture have not been carried out } \\
\text { by infection prevention and control } \\
\text { guidelines. Ministry of Health. }\end{array}$ \\
\hline 7. & 2020 & Niken Yulika & $\begin{array}{l}\text { Analysis of the } \\
\text { Implementation of }\end{array}$ & $\begin{array}{l}\text { The results of this study indicate } \\
\text { that nurses most often wash their }\end{array}$ \\
\hline
\end{tabular}


Volume I Tahun 2021

November 2021
E-ISSN: 2808-5361

http://e-journal.fkmumj.ac.id/
Proceeding The First

Muhammadiyah

Internasional- Public Health

and Medicine Conference

\begin{tabular}{|c|c|c|c|c|}
\hline No & Tahun Terbit & Nama Penulis & Judul & Hasil \\
\hline & & & $\begin{array}{l}\text { Nosocomial Infection } \\
\text { Prevention and } \\
\text { Control in the ICU } \\
\text { Room of RSUD dr. } \\
\text { Rasidin Padang } 2020\end{array}$ & $\begin{array}{l}\text { hands after contact with patients, } \\
\text { and rarely wash their hands before } \\
\text { contacting patients. The steps in } \\
\text { washing hands have not all been } \\
\text { done. PPE is available but the use } \\
\text { of PPE is not optimal. Etiquette } \\
\text { when coughing and sneezing has } \\
\text { not been carried out by all officers, } \\
\text { while the practice of safe injection } \\
\text { has been carried out } 100 \% \text {. }\end{array}$ \\
\hline
\end{tabular}

\begin{tabular}{|c|c|c|c|c|}
\hline 8. & April 2020 & $\begin{array}{l}\text { Andi Cahya Amalia } \\
\text { Ramadhani, Nani } \\
\text { Yuniar, Hilda } \\
\text { Harun }\end{array}$ & $\begin{array}{l}\text { Analysis of the } \\
\text { Implementation of } \\
\text { the Management of } \\
\text { the HAIs } \\
\text { (Healthcare- } \\
\text { Associated } \\
\text { Infections) } \\
\text { Prevention and } \\
\text { Control Program at } \\
\text { the Kendari City } \\
\text { Hospital in } 2020\end{array}$ & $\begin{array}{l}\text { The results showed that there were } \\
\text { still PPI officers who had not } \\
\text { attended PPI training and education } \\
\text { and did not understand their duties } \\
\text { and functions so that it had an } \\
\text { impact on the implementation of } \\
\text { tasks that were not optimal and the } \\
\text { lack of awareness of officers } \\
\text { regarding the use of PPE, hand } \\
\text { hygiene and the application of } \\
\text { bundles according to the guidelines. }\end{array}$ \\
\hline 9. & August 2019 & $\begin{array}{l}\text { Yayang } \\
\text { Khairunnisa Agusti, } \\
\text { Antono Suryoputro, } \\
\text { Wulan } \\
\text { Kusumastuti }^{2}\end{array}$ & $\begin{array}{l}\text { Analysis of } \\
\text { Management } \\
\text { Implementation of } \\
\text { the Healthcare- } \\
\text { Associated Infections } \\
\text { Prevention and } \\
\text { Control Committee at } \\
\text { Tugurejo Hospital, } \\
\text { Central Java Province }\end{array}$ & $\begin{array}{l}\text { PPI committee members have not } \\
\text { received training evenly, there is no } \\
\text { commitment from all officers } \\
\text { involved in the PPI program, there } \\
\text { are no incentives for PPI committee } \\
\text { members, there is an unbalanced } \\
\text { workload among PPI committee } \\
\text { members, there are still shortages } \\
\text { and delays in providing PPI } \\
\text { facilities, and compliance officers } \\
\text { on hand hygiene is still around } \\
80 \% \text {. }\end{array}$ \\
\hline 10. & June 2018 & $\begin{array}{l}\text { Vivi Syofia } \\
\text { Sapardi, Rizanda } \\
\text { Machmud, Reni } \\
\text { Prima Gusty }\end{array}$ & $\begin{array}{l}\text { Analysis of the } \\
\text { Implementation of } \\
\text { Management of } \\
\text { Prevention and } \\
\text { Control of } \\
\text { Healthcare- } \\
\text { Associated Infections } \\
\text { at RSI Ibnusina }\end{array}$ & $\begin{array}{l}\text { The results of this study identified } 4 \\
\text { themes, namely the implementation } \\
\text { of the HAIs program was not } \\
\text { optimal, the implementation of } \\
\text { HAIs implementation management } \\
\text { was not optimal, the results of the } \\
\text { implementation of the HAIs } \\
\text { implementation were not optimal } \\
\text { and obstacles in the implementation } \\
\text { of HAIs. }\end{array}$ \\
\hline
\end{tabular}

Based on the research conducted by Sukfitrianty Syahrir et al in 2018 regarding the Analysis of the Implementation of Prevention and Control of Nosocomial Infections in the ICU of Labuang Baji Hospital Makassar, it was found that the implementation of universal precautions was carried out by 
Volume I Tahun 2021

November 2021
E-ISSN: $2808-5361$

http://e-journal.fkmumj.ac.id/
Proceeding The First

Muhammadiyah

Internasional- Public Health

and Medicine Conference

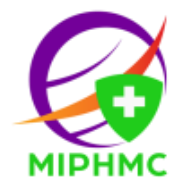

washing hands with hand wash and hand rub. Use of Personal Protective Equipment is used based on each indication. Management of medical devices is carried out at CSSD (Central Sterile Supply Department). Waste treatment is separated by type and temporary storage is carried out. Airborn precaution placing the patient in the RPK (Special Treatment Room) and using a special mask (N95). Droplet precaution patients can be placed in RPK, ICU isolation rooms, or ordinary beds. The patient's contact precautions are placed in a regular patient bed. This research was conducted with a descriptive qualitative approach with the method of determining informants and using purposive selected, and the informants in this study consisted of 7 informants (Syahrir et al., 2016).

In addition, another study conducted by Ramayanti, Rima Semiarty, and Yuniar Lestari in 2019 regarding the Analysis of the Implementation of the Nosocomial Infection Prevention and Control Program at the West Pasaman Hospital (Accreditation Standard Version 2012) found that there were obstacles in implementing the PPI in West Pasaman Hospital after analyzed with a systems approach. Input constraints are human resources, funds, and facilities, while the process is not optimal because there are still officers who have not carried out according to Standard Operating Procedures (SOP). The achievement of the PPI program is by the 2012 version of the accreditation standard, it only needs to strengthen commitment by all hospital staff. This study was conducted with a qualitative approach, aiming to obtain a deeper picture of information about the implementation of the nosocomial infection prevention and control program (Ramayanti, Semiarty, and Lestari, 2019).

Along with Agusti et al's previous research in 2019 regarding the Analysis of Management Implementation of the Healthcare-Associated Infections Prevention and Control Committee at Tugurejo Hospital, Central Java Province, it was found that the implementation of the PPI committee management at Tugurejo Hospital was not optimal. This study uses a qualitative method where information is obtained from in-depth interviews with the Main Informants, namely the Chair of the PPI Committee, 1 IPCD, 2 IPCN, and 2 IPCLN. As for the Triangulation Informants, namely the Deputy Director of Services, 2 Heads of Room, and 1 Head of Installation. The variables studied were input, process, and output from the implementation of the PPI committee management. They found that the PPI committee members had not received equal training, there was no commitment from all officers involved in the PPI program, there were no incentives for PPI committee members, there was an unbalanced workload among the PPI committee members, there were still shortages and delays in the provision of PPI facilities. , and officer compliance with hand hygiene is still around 80\% (Agusti, Suryoputro, and Kusumastuti, 2019). 
Volume I Tahun 2021

November 2021
E-ISSN: 2808-5361

http://e-journal.fkmumj.ac.id/
Proceeding The First

Muhammadiyah

Internasional- Public Health

and Medicine Conference

Another study conducted by Tetyana Madjid and Adik Wibowo in 2017 regarding the Analysis of the Application of Infection Prevention and Control Programs in the Inpatient Room of Tebet Hospital in 2017 obtained results which stated that most of the 4 actions had been carried out by nurses well, data analysis used univariate, bivariate, multivariate logistic regression. The variable that most influenced the action was the reporting of infection. This study uses a qualitative and quantitative approach, the unit of analysis is 105 the number of actions (Madjid and Wibowo, 2017).

Furthermore, research conducted by Mufidah Al'amri in 2017 regarding the Analysis of the Implementation of Infection Prevention and Control at the Anutapura General Hospital Palu-Central Sulawesi which stated that the number of infection cases in the hospital was still high, this was evidenced by the results of interviews and direct observations made researchers where the infection rate, especially phlebitis, is still above the established standard. In addition, the follow-up of infection cases in hospitals is still slow to be handled by the PPI committee This study uses a descriptive qualitative approach with a phenomenological design. The informants obtained were as many as 15 people. The results of this study recommend that the program, infection prevention, and control at the Anutapura Palu General Hospital be further improved, especially for reporting and follow-up of the incidence of infection in the hospital (Al'Amri, 2017).

In contrast to previous research, Anugrah Perdana Masolman (2015) in his research on the Analysis of the Implementation of Infection Prevention and Control in the Operating Room of Dr. Sam Ratulangi Hospital Tondano explained that the implementation of hand hygiene, use of personal protective equipment, processing of patient equipment, waste management, environmental management, programs the health of health workers, patient placement, respiratory hygiene, safe injection practices and practices for lumbar puncture have not been carried out by the infection prevention and control guidelines of the Ministry of Health. This research is descriptive using a qualitative method that aims to obtain more in-depth information about the implementation of infection prevention and control in the operating room of RSUD DR. Sam Ratulangi Tondano (Masloman, Kandou and Tilaar, 2015).

Niken Yulika's research (2020) with the title Analysis of the Implementation of Prevention and Control of Nosocomial Infections in the ICU Room of RSUD dr. Rasidin Padang in 2020 stated that nurses most often wash their hands after contact with patients, and rarely wash their hands before contacting patients. The steps in washing hands have not all been done. PPE is available but the use of PPE is not optimal. Etiquette when coughing and sneezing has not been carried out by all officers, while the practice of safe injection has been carried out $100 \%$. His research uses Mix-Method with a concurrent 
Volume I Tahun 2021

November 2021
E-ISSN: 2808-5361

http://e-journal.fkmumj.ac.id/
Proceeding The First

Muhammadiyah

Internasional- Public Health

and Medicine Conference

embedded strategy model. Qualitative research was conducted on 6 informants and determined based on purposive sampling. Quantitative research was conducted by observing 3 nurses on duty on 3 work shifts for 7 consecutive days (Yulika, 2020).

Then the research conducted by Ramadhani, Yuniar, and Harun in 2020 regarding the Analysis of the Implementation of the Management of the Prevention and Control of HAIs (Healthcare-Associated Infections) Programs at the Kendari City Hospital in Tahunan, the results showed that there were still PPI officers who had not attended PPI training and education and do not understand their duties and functions so that it has an impact on the implementation of tasks that are not optimal and the lack of awareness of officers regarding the use of PPE, hand hygiene and the application of bundles according to the guidelines. This research is qualitative research with a case study approach. Research informants are IPCN, IPCD, IPCLN, and Members officers (Ramadhan, Yuniar, and Harun, 2020).

Another study conducted by Austi, Suryoputro, and Kusumastuti in 2019 regarding the Analysis of Management Implementation of the Healthcare-Associated Infections Prevention and Control Committee at Tugurejo Hospital, Central Java Province, obtained similar results that there are still PPI committee members who have not received equal training, there is no commitment of all officers involved in the PPI program, there are no incentives for PPI committee members, there is an unbalanced workload for PPI committee members, there are still shortages and delays in providing PPI facilities, and officers' compliance with hand hygiene is still around $80 \%$. Methods The research uses qualitative methods where information is obtained from in-depth interviews with key informants, namely the Chair of the PPI Committee, 1 IPCD, 2 IPCN, and 2 IPCLN. As for the Triangulation Informants, namely the Deputy Director of Services, 2 Heads of Room, and 1 Head of Installation. The variables studied were inputs, processes, and outputs from the implementation of the PPI committee management (Agusti, Suryoputro, and Kusumastuti, 2019).

Then the research conducted by Sapardi, Machmud, and Gusty in 2019 regarding the Analysis of the Implementation of Management of Prevention and Control of Healthcare-Associated Infections at Ibnusina Hospital identified 4 themes, namely the implementation of the HAIs program was not optimal, the implementation of HAIs implementation management was not optimal, the results of the implementation of HAIs were not optimal and obstacles in the implementation of HAIs.

The results of the research from the 10 journals, found that there are still some hospitals that have not been optimal in implementing the PPI including the steps in washing hands not all of them have been carried out by officers, PPE is available but the use of PPE correctly is not maximized. Ethics when 
E-ISSN: 2808-5361

http://e-journal.fkmumj.ac.id/
Proceeding The First

Muhammadiyah

Internasional- Public Health

and Medicine Conference

coughing and sneezing have not been carried out by all officers, PPI officers who have not attended PPI training and education and do not understand their duties and functions so that it has an impact on the implementation of tasks that are not optimal and lack of awareness of officers regarding the use of PPE, hand hygiene and the application of bundles according to guidelines.

According to the Ministry of Health of the Republic of Indonesia, 2011, prevention and control of nosocomial infections is a challenge worldwide because it can increase morbidity and mortality and increase health costs due to additional time for treatment and hospital care. The risk of infection in the hospital or commonly known as the nosocomial infection is an important problem throughout the world. This infection continues to increase from $1 \%$ in some European and American countries, to more than $40 \%$ in Asia, Latin America, and Africa.

The implementation of PPI in health care facilities must be managed and integrated between structural and functional all departments/agencies/divisions/units in health service facilities by the philosophy and objectives of IPC. Procedures for infection prevention and control measures absolutely must be applied in hospitals, including in operating rooms. The operating room is a special unit in a hospital where surgery is performed. Preventing infection after surgery is a complex process that begins in the operating room by preparing and maintaining a safe environment for surgery (Riani and Syafriani, 2019).

One of the efforts to prevent nosocomial infections is to do hand hygiene. Hand hygiene according to the Indonesian Infection Control Association is a procedure for cleaning hands using soap or antiseptic under running water or by using a hand scrub that aims to remove dirt from the skin mechanically and reduce the number of microorganisms. Hand hygiene is the most important measure in preventive measures because it is more effective and low cost, it is estimated that doing hand hygiene can reduce the impact on nosocomial infections by 50\% (Riani and Syafriani, 2019).

Nosocomial infections will not occur if nurses comply with the principles of hand washing or hand hygiene based on the crew survey that the researchers conducted, namely the nurse's compliance in carrying out hand hygiene at the AH hospital is still relatively low, and the nurse's compliance rate in carrying out hand hygiene in the 2018 period based on data from the PPI Committee (Committee on Infection Prevention and Control) at the AH hospital with an average of 59.3\%. The lack of compliance is motivated by the motivation of nurses in doing good and correct 6-step hand hygiene, which is also still lacking (Riani and Syafriani, 2019). 
E-ISSN: 2808-5361

http://e-journal.fkmumj.ac.id/
Proceeding The First

Muhammadiyah

Internasional- Public Health

and Medicine Conference

The Infection Prevention and Control Program (PPI) is very important to be implemented in hospitals and other health care facilities as a place for health services as well as as a benchmark for service quality as well as to protect patients, officers, visitors, and families from the risk of contracting infections due to being treated, assigned and visited. a hospital or other health care facility. The risk of infection in hospitals or commonly known as Healthcare-Associated Infections (HAIs) is an important problem throughout the world (Sapardi, Machmud, and Gusty, 2018).

\section{CONCLUSIONS AND SUGGESTIONS}

Based on the results of research that has been carried out by researchers, it can be concluded that 10 journals have been reviewed using the literature review method. 8 journals have problems, with results such as lack of Human Resources (HR), insufficient funds and infrastructure, there are still many officers who have not taken action according to Standard Operating Procedures (SOP), many officers have not received training, there is no incentive to officers, there is an unbalanced workload, the reporting system is not maximized, the use of Personal Protective Equipment (PPE) is not optimal, and cough etiquette has not been carried out by officers.

So it is necessary to add things that must be met, such as training of officers, completing the needs (facilities and infrastructure) for officers, providing sanctions for officers when violating (not taking action according to SOPs), providing incentives for officers, and even giving awards for officers who obediently carry out according to the SOP, especially given strict supervision from the hospital so that officers and patients can both not transmit the disease to officers or other people.

\section{REFERENCES}

Agusti, Y. K., Suryoputro, A. and Kusumastuti, W. (2019) 'Analysis of Management Implementation of the Healthcare-Associated Infections Prevention and Control Committee at Tugurejo Hospital, Central Java Province', Indonesian Public Health Media, 18(4), pp. 147-152.

Agusti, Y. K., Suryoputro, A. and Kusumastuti, W. (2019) 'Analysis of Management Implementation of the Healthcare-Associated Infections Prevention and Control Committee at Tugurejo Hospital, Central Java Province'.

Al'Amri, M. (2017) 'Analysis of the Implementation of Infection Prevention and Control at Anutapura General Hospital Palu, Central Sulawesi'. 
E-ISSN: 2808-5361

http://e-journal.fkmumj.ac.id/
Proceeding The First

Muhammadiyah

Internasional- Public Health

and Medicine Conference

Cahya, A. et al. (2020) 'Analysis of the Implementation of the Management of the Prevention and Control of Menstrual Infections (Healthcare-Associated Infections) Program at the Kendari City Hospital in 2020', 1(1), pp. 23-34.

Heriyati, Hatisah, and Astuti, A. (2020) 'Relationship of Knowledge with Prevention and Control of Nosocomial Infections in Hospitals', Journal of Health Education, 9(1), pp. 87-92.

Jurnal Endurance, 3(2), p. 358. doi:10.22216/jen.v3i2.3029.

Madjid, T. and Wibowo, A. (2017) 'Analysis of the Implementation of Infection Prevention and Control Programs in the Tebet Hospital Inpatient Room in 2017', Arsi, 4(1), pp. 57-68.

Madjid, T. and Wibowo, A. (2017) 'Analysis of the Implementation of Infection Prevention and Control Programs in the Tebet Hospital Inpatient Room in 2017', 4, pp. 57-68.

Masloman, An. P., Kandou, G. D. and Tilaar, C. R. (2015) 'Analysis of the Implementation of Infection Prevention and Control in the Operating Room of Dr. Sam Ratulangi Hospital Tondano Implementation Analysis of Prevention and Control of Infection in Operating', pp. 238-249.

Ministry of Health of the Republic of Indonesia (2011) 'The Nosocomial Infection Prevention and Control Program is an Element of Patient Safety', Article, pp. 1-2. Available at: https://www.kemkes.go.id/article/view/1710/program-pentangan-dan-control-infectionnosokomial-merupakan-elemen-patient-safety.html.

Puspitasari, R. W. (2020) 'Overview of Hand Hygiene Compliance in Intensive Care Patients' Families in Preventing the Occurrence of HAI at RSU Dr. H. Koesnadi Bondowoso'.

Ramadhan, A. C. A., Yuniar, N., and Harun, H. (2020) 'Analysis of Management Implementation of the Prevention and Control of Menstrual Infections (Healthcare-Associated Infections) Program in Kendari City Hospital in 2020', 1(1), pp. 23-34.

Ramayanti, Semiarty, R. and Lestari, Y. (2019) 'Analysis of the Implementation of the Nosocomial Infection Prevention and Control Program in West Pasaman Hospital (Accreditation Standard Version 2012)', 8(3), pp. 617-626.

Riani and Syafriani (2019) 'The Relationship Between Motivation and Compliance of Nurses Implementing Hand Hygiene as a Prevention of Nosocomial Infections in the Inpatient Room of Hospital A', Journal of Ners, 3(23), pp. 49-59. Available at: https://journal.universitaspahlawan.ac.id/index.php/ners/article/view/405/340.

Salawati, L. (2012) 'Control of Nosocomial Infections in Intensive Care Unit Hospitals', Syiah Kuala Medical Journal, 12(1), pp. 47-52. 
Sapardi, V. S., Machmud, R. and Gusty, R. P. (2018) 'Analysis of the Management of Prevention and Control of Healthcare-Associated Infections in Rsi Ibnusina', Sundoro, T. (2020) 'Program for Prevention and Control of Healthcare-Associated Infections (HAIs) at Hospital X Yogyakarta Program for Prevention and Control of Healthcare-Associated Infections (HAIs) in Hospital X Yogyakarta', Journal of Periodic Public Health Sciences (JIKeMB), 2( 2), pp. 25-35.

Syahrir, S. et al. (2016) 'Analysis of the Implementation of Prevention and Control of Nosocomial Infections in the ICU of Labuang Baji Hospital Makassar', 2010.

Yulika, N. (2020) 'Analysis of the Implementation of Prevention and Control of Nosocomial Infections in the ICU Dr. Hospital. Rasidin Padang in 2020', Thesis. 